\title{
The Effect of Using Comic Strips on The Eighth Grade Students' Narative Writing Achievement at SMP Negeri 5 Jember
}

\author{
Ika Fitriani Martages, Bambang Suharjito, Asih Santihastuti \\ Language and Arts Education Program, The Faculty of Teacher Training and Education, Jember Universtity \\ Jln. Kalimantan 37, Jember 68121 \\ E-mail: ikamartages11@gmail.com
}

\begin{abstract}
The aim of this research was to investigate whether or not there was a significant effect of using Comic Strips on the eighth grade students' narrative writing achievement at SMP Negeri 5 Jember. The research design used was quasi-experimental research with post-test only design. The respondent of the research was chosen by using cluster random sampling. Two of the seven classes were selected as the experimental group and the control group. Through a lottery, class VIII-F was chosen as the experimental group and class VIII-E was chosen as the control group. The data was selected by writing test. Then, the data collected were analyzed by using independent sample t-test. Based on the result of the posttest scores, the mean score writing post-test in experimental group was 76.8000 while the mean score of control group was 70.5156. Moreover, based on the output of Independent sample t-test, the value of sig column of Lavene's test was 0.020 and this value was lower than 0.05 . It indicated that the result of $t$-test analysis was significant. It meant that the result of this research proved that the use of Comic Strips significantly affected the eighth grade students narrative writing achievement at SMP Negeri 5 Jember. It can be seen, especially, from the content and language use.
\end{abstract}

Keywords : Writing, Writing Achievement, Comic Strips, Media

\section{Introduction}

Tangpermpoon [1] states that writing is considered as the most difficult skill for language learners because they need to have a certain amount of language learning background knowledge about the rhetorical organizations, appropriate language use or specific lexicon with which they want to communicate to their readers. Thus, we cannot define writing just as a simple thing to do. It means that writing is a complex process which needs skill and practice. Writing is one of the most important aspects in English language acquisition although it is quite difficult to master writing, especially for EFL students in Indonesia, since there are some differences between Bahasa Indonesia and English such as grammatical and structural terms and styles. Furthermore, in the process of writing, the EFL students have to struggle in putting ideas or arguments on the paper. They have to spend too much time in finding out the ideas about the topic given to write because they do not have enough basic knowledge and interest in writing. It is related to fundamental problem in terms of interest in learning writing. Therefore, the English teachers have to determine the effective strategies to improve their interest and ability in writing. One of the main problems that leads to the low interest in writing is the lack of media. Therefore, the students need media to stimulate and activate their ideas in order to produce a piece of writing more easily. Thus, media are expected to create a more interesting writing class.

Media can also be used to transfer the learning material to reach the goal of study and increase the students' achievement. The researcher considered to use comic strips as visual media and appropriate strategy to develop the students' skill in producing writing. As stated by Wright \&
Sherman [2], the teachers should use comic strips in language art classroom for three reasons. First, there is a great students' interest in the genre. It means that comic strips is one of the most loved genre of reading by students as comic tells about casual situation and many with funny or interesting story and illustration. Second, they are inexpensive to obtain. As we know in this era of technology we can get or download sources of material from the internet easily. Therefore, the teacher should be able to consider comic strips in order to make appropriate materials that they are going to teach. Third, most comic strips have low readability levels, with a paucity of words and sentences which are linguistically ideal for elementary and middle school readers. It means that the vocabulary is not too difficult and appropriate with the students' level so they are able to understand the content of comic strips easily.

The researcher decided to create comic strips by herself using website on the internet. The name of the website is Toondoo.com. It is a free website that allows people around the world to create comic strips. In education, it helps the teacher in their teaching by using comic strips. The teacher can create the story based on their desires which combine it with the characters and situations. They do not have to download anything on the website in creating the comic strips.

The previous researchers found that comic strips could improve the students' writing achievement. A research conducted by Utomo [3] concluded that there was a significant effect of using comic strips on the eleventh grade students' spoof writing achievement. Another researcher Eldina [4] also found there was a significant effect of using comic strips on eighth grade students' recount writing achievement. Based on these previous studies, the results show that the use of comic strips can help the students start 
writing and developing their ideas. The researcher chose a narrative text in this research for completing the previous researches.

According to the curriculum (KTSP/2013), students study at the eighth grade of junior high school are required to be able to understand and create various written texts, monologue, and essay in the form of procedure, descriptive, recount, narrative, report, news item, analytical exposition, hortatory exposition, spoof, explanation, discussion, review, public speaking (Depdiknas, [5]) This research only focuses on narrative text because it consists of telling a story, having characters, setting, and actions, these are suitable with the features in the comic strips.

Considering the description above, it is necessary to conduct a research entitled "The Effect of Using Comic Strips on the Eighth Grade Students' Narrative Writing Achievement at SMP Negeri 5 Jember in the 2016/2017 Academic Year."

The researcher was interested in conducting this research because the teaching of writing by using comic strips has never been applied at this school.

\section{Research Method}

This research used quasi-experimental design with post-test only design. As stated by Bieger \& Gerlach [6] this design would only be useful if the researcher was confident about the equality of the students' ability. Thus, the researcher conducted the homogeneity test to know whether the students' ability, particularly on their writing ability, is equal or not.

According to Fraenkel et.al [7], in an experimental research, the researcher manipulated the independent variable. They brought out that the experimental group received a treatment of some sorts (such as the use of media), while the control group received no treatment. The control group was very important to enable the researcher determined whether the treatment had an effect or whether one treatment was more effective than another. The two classes were chosen as the experimental and the control groups randomly since the population was homogeneous. The treatment was given to the experimental group and was not given to the control group. The experimental group was taught writing (narrative) by using comic strips, while the control group was taught writing (narrative) without using comic strips.

This research used purposive method in selecting area of the research. In this research, the area chosen was SMP Negeri 5 Jember. The population of this research was the eighth grade students of SMP Negeri 5 Jember. For determining the samples, the research chose two classes from the seven classes by using random sampling. Since the population was homogeneous, the researcher chose two classes randomly and did lottery to determine the experimental and control group. Through a lottery, VIII-F was chosen as the experimental and VIII-E as the control group.

\section{The Research Findings}

The post test result was analyzed by using independent sample t-test to know whether the mean difference the experimental group and control group was significant effect or not. The result of the output of independent sample t-test can be seen in the following table.

Table 1. The Output of Statistical Description

Group Statistics

\begin{tabular}{|ll|r|r|r|r|}
\hline & \multicolumn{1}{|c|}{$\mathrm{N}$} & Mean & Std. Deviation & $\begin{array}{c}\text { Std. Error } \\
\text { Mean }\end{array}$ \\
\hline SCORE & Experimental Group & 30 & 76.8000 & 6.22232 & 1.13603 \\
& Control Group & 32 & 70.5156 & 4.05503 & .71684 \\
\hline
\end{tabular}

Table 2. Output of Independent Sample t-test

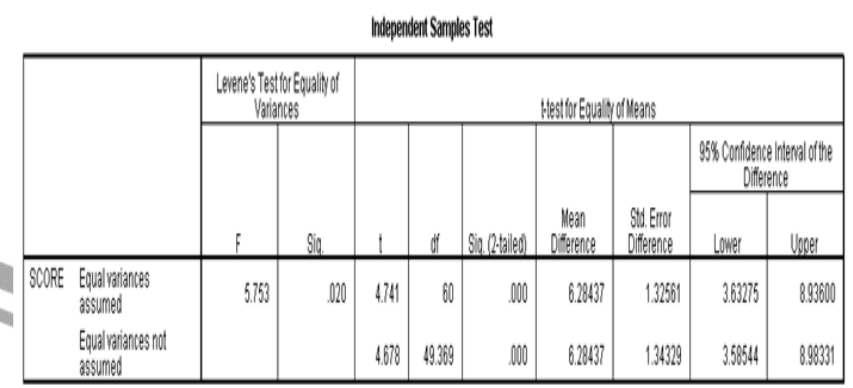

Based on the table of group statistics, the mean score of post-test in experimental group was 76.8000 , while the mean score of control group was 70.5156. Moreover, based on the output of Independent sample t-test, the value of sig. column of Lavene's test was 0.020. It was lower than 0.05 . Consequently, the row that must be read was the second row of t-test column. In t-test column, the value of sig column in Levene's test for equality of variances column was 0.020 . As it was lower than 0.05 , the null hypothesis $\left(\mathrm{H}_{0}\right)$ was rejected. Thus, the second row was 0.000 . Because it was lower than 0.05 , the alternative hypothesis $\left(H_{a}\right)$, which was formulated: "there is a significant effect of using comic strips on the eighth grade students' narrative writing achievement at SMP Negeri 5 Jember", was accepted. It means that there was a significant effect of using comic strips on the eighth grade students' narrative writing achievement at SMP Negeri 5 Jember.

Discussion

Based on the result of independent sample t-test, the significance value of t-test (2-tailed) was 0.000 and it was less than 0.05 . It indicated that the result of $t$-test analysis was significant. It means that the result of this research proved that the use of Comic Strips significantly affected the eighth grades students' narrative writing achievement at SMP Negeri 5 Jember.

In this research, the result showed that the experimental group got better results in writing achievement. It happened because the use of comic strips could attract the students' attention. This attraction affected the students' motivation in learning writing English well. This research proved the theory that Csabay [8] and Yang [9] who stated that one of the strongest benefits of using comic strips to teach is the ability to motivate the students since it brings a cheerful atmosphere into the class. The evidence was the students in experimental group which were taught by using comic strips as media in writing class could develop their writing skills. They paid more attention. Comic strips made them excited in learning activity both reading comic strips and writing narrative text using comic strips. Thus, the use of comic strips in teaching writing gave good benefit to gain the 
students' motivation and improve their achievement.

Hutchinson's experiment (in Yang,[9]) stated that many teachers discovered comic strips to be particularly useful in classroom. By using comic strips as media, teacher can take the advantage of them as an intermediary or a medium to help the students in gaining ideas in the process of writing. The teachers can accomplish the assignment by using comic strips as both a method and medium of instruction. It showed that the use of comic strips in teaching writing has good effect. By using comic strips in teaching narrative writing, the teacher could reach the goal of study and improved the students' achievement. It can be seen when the students in experimental group got high score in content and language use. It is higher than the score in control group. It bas proved that using media like comic strips in teaching writing has good effect for the students.

Furthermore, previous researchers found that comic strips could improve the students' writing achievement. A research conducted by Utomo [3] concluded that there was a significant effect of using comic strips on the eleventh grade students' spoof writing achievement. Another researcher Eldina [4] also found there was a significant effect of using comic strips on eighth grade students' recount writing achievement. Based on these previous studies, the results showed that the use of comic strips can help the students start writing and developing their ideas.

In the first meeting, the researcher asked the students' prior knowledge about a fable story such as "The Fox and the Cat" and narrative text. After that, the researcher explained about definition, social function, generic structures and language features of a narrative text. This step was called Building Knowledge of Field (BKoF). The next step was Modeling of the Text (MoT), researcher gave the comic strip related to the model of a narrative text entitled "The Fox and the Cat". In this step, the researcher taught the students to identify the generic structures and language features of narrative text, change the form of verb 1 into verb 2 , direct speech into indirect speech, make supporting sentences based on the information from comic strips and arrange the sentences into a good narrative text. Afterwards, in Joint Construction of the Text (JCOT) step, the researcher distributed the comic strip entitled "The Bear and Tortoise." The students were asked to discuss it in pairs. Once the discussion was over, the last step was Independent Construction of the Text (ICoT), researcher asked the students to compose a narrative text about "The Bear and Tortoise" trough process writing individually. They were asked to compose a piece of writing of around 70-100 words in 40 minutes. The students' results of writing were submitted and assessed by the researcher and the English teacher. The researcher did the same steps in the second meeting; she also reviewed the explanation about narrative text and evaluated the previous students' result of writing to share a better understanding, so that the students could gain a better score of writing.

\section{Conclusion and Suggestion}

Based on the data analysis, hypothesis verification, and discussion in the previous chapter, it can be concluded that there was a significant effect of using comic strips on the eighth grade students' narrative writing achievement at SMP Negeri 5 Jember in the 2016/2017 academic year and the use of comic strips in teaching writing to the eighth grade students of SMP Negeri 5 Jember in the 2016/2017 academic year was $8,9120 \%$ more effective than teaching and learning process without comic strips at SMP Negeri 5 Jember. In order to make the teaching and learning class are meaningful and to improve the quality of the English teaching and learning process in the future, the English teacher of SMP Negeri 5 Jember should use comic strips in teaching writing as the media to increase the students' narrative writing achievement because the finding of this research was proved that the use of comic strips has significant effect in students' writing achievement. For the future researchers, the result of this research can be used as reference and information to conduct further research dealing with a similar topic by using a different genre text, different website to create comic strips, different research design or in different research area.

\section{References}

[1] Tangpermpoon, T. 2008. Integrated Approaches to Improve Students Writing Skills For English Major Students. ABAC Journal. 28 (2) 1-9. Available:

http://www.journal.au.edu/abac journal/2008/may08/01\%2819\%29_a rticle01.pdf

Wright, G. \& Sherman, R. 1999. Let's Create a Comic Strip. Available: http://web.ebscohost.com/ehost/ delivery?sid=70ecaflb-79c9-4fd19f.pdf

Utomo, P.N. 2013. The Effect of Using Comic Strips on the Eleventh Grade Students' Spoof Writing Achievement at SMAN I Kencong in the 2012/2013 Academic Year. (Unpublished thesis). Jember: Jember University.

4] Eldina, H. 2014. The Effect of Using Comic Strips on the Eighth Grade Students Recount Writing Achievement at SMPN 1 Jember in the 2013/2014 Academic Year. (Unpublished thesis). Jember: Jember University.

[5] Badan Standar Nasional Pendidikan. 2006. Standar Kompetensi Mata Pelajaran Bahasa Inggris untuk SMP. Jakarta: Pusat Kurikulum, Badan Penelitian dan Pengembangan Departemen Pendidikan Nasional.

[6] Bieger, G. R. \& Gerlach, G. J. 1996. Educational Research: A Practical Approach. New York: Delmar Publishers.

[7] Fraenkel, J.R., Wallen, N.E., \& Hyun, H.H. 2012. How to Design and Evaluate Research in Education. New York: The McGraw-Hill Companies, Inc.

[8] Csabay, N. 2006. Using Comic Strips in Language Classes. Available: http://americanenglish.state.gov/ files/ae/resource files/06-44-1-f.pdf

[9] Yang, G. 2003. Comics in Language Education online version of the final project for Masters of Education degree of the author at California State University at Hayward. Available: http://www.humblecomics.com/ comicsedu/strengths.html 